\title{
The Effects of In-Ovo Injection of Glucose on Hatchability, Hatching Weight and Subsequent Performance of Newly-Hatched Chicks
} ISSN 1516-635X Apr - Jun 2012/ v.14 / n.2 / 71-158

\section{-Author(s)}

Salmanzadeh M

Departmens of Animal Science, Shabestar branch, Islamic Azad University, 53815-159 Shabestar, Iran

\section{Mail Adress}

* Corresponding author: Mehdi Salmanzadeh, Departmens of Animal Science, Shabestar branch

Islamic Azad University,

53815-159

Shabestar, Iran.

E-mail: salmanzadeh_mehdi@yahoo.com

\section{Eeywords}

broiler, in-ovo injection, glucose, hatching traits, performance.

\begin{abstract}
This experiment was conducted to determine the effects of an in-ovo injection of glucose on hatchability, weight and subsequent performances of newly-hatched chickens. The 720 fertile eggs used in this experiment were obtained from a Cobb-500 broiler breeder flock of 28 weeks of age. Treatments were the following: 1) control group (withou- injection), 2) group injected with $0.5 \mathrm{ml}$ deionized water (sham group), 3) group injected with $0.5 \mathrm{ml}$ glucose $15 \%$ in deionized water, 4) group injected with $0.5 \mathrm{ml}$ glucose $20 \%$ in deionized water and 5) group injected with $0.5 \mathrm{ml}$ glucose $25 \%$ in deionized water. There werh four replicates per treatment and 36 eggs per replicate. The experimental design was a completely randomized design. Upon hatch, hatchability and weight of newly-hatched chicks were measured, and 20 chicks per replicate were transferred to an experimental house and reared for 42 days. Live weight and feed intakeswere measured for each experimental unit at 21 and 42 days of age and then weight gai, and feed conversion ratio were calculated. The results of the study indicate that group that received glucose at 15\%,20\% and 25\% had significantly higher hatching weight as compared with the control and the sham groups, tbut,eggs injected in ovo had significantly lower hatchability than the controls $(p<0.01)$. Also, there were no significant treatment effects on feed intake between 0 and 21 days post-hatch. Chicks that received in-ovo injection of glucose haddbetter feed intake, weight gain and feed conversion ratio compared with chicks hatched from the control and the sham groups. The obtained Data suggest that in-ovo injection may increase weight and improve the performancs of newly-hatched chickens.
\end{abstract}

\section{INTRODUCTION}

The injection oN nutrients in ovo may provide poultry companies with an alternative method to increase hatchability and the weight of newly-hatched chick (Ohta et al., 2001). Glucose is the main energy source of living organisms (Stryer, 1995). Ingram et al. (1997b) investigated the effect of in-ovo injection of different levels glucose in broiler eggs prior to transfer to the hatcher on the hatchabilit chick weight, and subsequent body weight, and reported that glucose significantly improved performancs. Accelerated embryo development and improved nutritional status afforded by in-ovo feeding improved hatching weight, growth rate (Al-Murrani, 1982; Ohta et al., 1999; Bhanja et al., 2004). Also, the rapid development of digestive organs during the final days of incubation implies that a large amount of energy is required to maintain the normal development of the embryo. However, limited glucose supply in latm incubation of poultry embryos induces gluconeogenesis from amino acids produced by the 
degradation of protein of the breast muscle (Hamer \& Dickson, 1989), which ultimately results in decreased protein deposition in breast muscle and organ weight decline (Vieira \& Moran, 1999). Therefore, the final days of incubation and the first few days after hatching are a critical period for the survival and development of embryos at the end of incubation and neonates in poultry because of considerable energy catabolism.

Glucose storage as glycogen was demonstrated to be a very important energy resource for maintaining normal metabolism and body growth duringrpre- and post-hatching days (Christensen et al., 2000). Itnwas demonstrated that in-ovo injectioneis an available tool to supply nutrient to embryos in previous research studies (Uni et al., 2005),sproviding a new insight into the nutritional manipulation of poultry embryos. We hypothesize that the exogenous supply of glucose by the method of in-ovo injection is likely to alleviate the crisis of energy supply in broiler embryos, and to improve hatchability, weight and subsequent performancs of newly-hatched chickens.

\section{MATERIALS AND METHODS}

This experiment was conducted at Islamic Azad Universit. Hhatchery farm during the summer of 2010. The 720 fertile eggs used in this experiment were obtained from a Cobb-500 broiler breeder flock of 28 weeks of age. All eggs were collected from the same breeder flock and weighed on a scale with $0.1 \mathrm{~g}$ precision.sEggsfweighed $60 \pm 1 \mathrm{~g}$ and were incubated at $37.8^{\circ} \mathrm{CC}$ and $63 \% \mathrm{RH}$ relativeyhumidity). Then, the eggs were divided into five groups; 1) control group (without injection), 2) group injected with 0.5 $\mathrm{ml}$ deionized water (sham group), 3) group injected with $0.5 \mathrm{ml}$ glucose $15 \%$ in deionized water, 4) group injected with $0.5 \mathrm{ml}$ glucose $20 \%$ in deionized water and 5) group injected with $0.5 \mathrm{ml}$ glucose $25 \%$ in deionized water. There werh four replicates per treatment and 36 eggs per replicate. Pure glucose was supplied by Merck Company (Item Catalog Number 108337.0250). Onyday 6 of incubation, eggs were candled, and unfertilized eggs or those containing dead embryos were discarded. On day 7 of incubation, eggs were removed from the incubator for $10 \mathrm{~min}$ to perform glucose injections that were carried out in the albumen of eggs. The control group was kept in the same environmental conditions during treatments. Upon hatch, 20 chicks per replicate were weighed and transferred to an experimental house for subsequent performance study. Chicks were reared up to $42 \mathrm{~d}$ of age and were supplied with a standard broiler feed (National Research Council, 1994). Food and water were available a- libitum. Body weight and feed intake were measured at 21 and 42 days of age and then feed conversion ratio was calculated. Treatments were analyzed by ANOVA using the general linear models procedure of SAS software package (SAS institute, 2001). When differences among means were found, means were compared by Duncan's multiple range tests.

\section{RESULTS}

Hatching weight was significantly higher when glucose was received as compared to the control and sham groups.yOn the other hand, in-ovo glucose administration significantly decreased hatchability $(p<$ 0.01 ) (Table 1). As shown in Table 2, in-ovo injection of glucose did notnsignificantly influence the feed intake of broiler chickens during the period of 1-21 day of age., bu feed intake was significantly higher in chicks hatched from eggs injected with glucosenboth during the period 21-42 days and total rearing period (1-42 days of age) compared with the control and the sham groups $(p<0.01)$. Chicks from eggs injected witf glucose had better weight gain and feed conversion ratioothan chicks hatched from the control and sham groupn throughout the experimental rearing period (Table 3 and Table 4).

Table 1 - Effect of in ovo injection of glucose on chick weight and hatchability of newly-hatched chickens.

\begin{tabular}{l|c|c}
\hline Groups & Chick weight (g) & Hatchability (\%) \\
\hline Control & $39.22^{\mathrm{b}}$ & $86.32^{\mathrm{a}}$ \\
Sham & $39.27^{\mathrm{b}}$ & $70.27^{\mathrm{bc}}$ \\
Glucose (15\%) & $40.24^{\mathrm{a}}$ & $67.50^{\mathrm{c}}$ \\
Glucose (20\%) & $40.16^{\mathrm{a}}$ & $72.52^{\mathrm{bc}}$ \\
Glucose (25\%) & $40.26^{\mathrm{a}}$ & $74.02^{\mathrm{b}}$ \\
\hline p - value & 0.0001 & 0.0001 \\
\hline SEM & 0.11 & 1.72 \\
\hline
\end{tabular}

Table 2 - Effect of in-ovo injection of glucose on the feed intake of broiler chickens during different periods.

\begin{tabular}{l|c|c|c}
\hline \multicolumn{1}{|c}{ Groups } & $\begin{array}{c}1-21 \text { days of } \\
\text { age } \\
(\mathrm{g})\end{array}$ & $\begin{array}{c}21-42 \text { days of } \\
\text { age } \\
(\mathrm{g})\end{array}$ & $\begin{array}{c}1-42 \text { days of } \\
\text { age } \\
(\mathrm{g})\end{array}$ \\
\hline Control & 744 & $3218^{\mathrm{b}}$ & $3962^{\mathrm{b}}$ \\
Sham & 750 & $3227^{\mathrm{b}}$ & $3976^{\mathrm{b}}$
\end{tabular}




\begin{tabular}{l|c|c|c} 
Glucose (15\%) & 754 & $3260^{\mathrm{a}}$ & $4013^{\mathrm{a}}$ \\
Glucose (20\%) & 759 & $3256^{\mathrm{a}}$ & $4016^{\mathrm{a}}$ \\
Glucose (25\%) & 755 & $3270^{\mathrm{a}}$ & $4025^{\mathrm{a}}$ \\
\hline $\mathrm{p}$ - value & 0.470 & 0.0001 & 0.0001 \\
\hline SEM & 6.03 & 5.42 & 6.70 \\
\hline
\end{tabular}

Table 3 - Effect of in-ovo injection of glucose on the body weight of broiler chickens during different periods.

\begin{tabular}{l|c|c|c}
\hline Groups & $\begin{array}{c}1-21 \text { days of } \\
\text { age } \\
(\mathrm{g})\end{array}$ & $\begin{array}{c}21-42 \text { days of } \\
\text { age } \\
(\mathrm{g})\end{array}$ & $\begin{array}{c}1-42 \text { days of } \\
\text { age } \\
(\mathrm{g})\end{array}$ \\
\hline Control & $549^{\mathrm{b}}$ & $1522^{\mathrm{b}}$ & $2071^{\mathrm{b}}$ \\
Sham & $540^{\mathrm{b}}$ & $1519^{\mathrm{b}}$ & $2059^{\mathrm{b}}$ \\
Glucose (15\%) & $567^{\mathrm{a}}$ & $1564^{\mathrm{a}}$ & $2131^{\mathrm{a}}$ \\
Glucose (20\%) & $564^{\mathrm{a}}$ & $1575^{\mathrm{a}}$ & $2139^{\mathrm{a}}$ \\
Glucose (25\%) & $571^{\mathrm{a}}$ & $1570^{\mathrm{a}}$ & $2141^{\mathrm{a}}$ \\
\hline p-value & 0.0007 & 0.0001 & 0.0001 \\
\hline SEM & 4.02 & 4.45 & 5.20 \\
\hline
\end{tabular}

Table 4 - Effect of in-ovo injection of glucose on the feed conversion ratio of broiler chickens during different periods.

\begin{tabular}{l|c|c|c}
\hline \multicolumn{1}{l|}{ Groups } & $\begin{array}{c}1-21 \text { days of } \\
\text { age } \\
(\mathrm{g})\end{array}$ & $\begin{array}{c}21-42 \text { days of } \\
\text { age } \\
(\mathrm{g})\end{array}$ & $\begin{array}{c}1-42 \text { days of } \\
\text { age } \\
(\mathrm{g})\end{array}$ \\
\hline Control & $1.35^{\mathrm{b}}$ & $2.11^{\mathrm{a}}$ & $1.91^{\mathrm{b}}$ \\
Sham & $1.38^{\mathrm{a}}$ & $2.12^{\mathrm{a}}$ & $1.93^{\mathrm{a}}$ \\
Glucose (15\%) & $1.32^{\mathrm{bc}}$ & $2.08^{\mathrm{b}}$ & $1.88^{\mathrm{c}}$ \\
Glucose (20\%) & $1.33^{\mathrm{bc}}$ & $2.06^{\mathrm{b}}$ & $1.87^{\mathrm{c}}$ \\
Glucose $(25 \%)$ & $1.33^{\mathrm{c}}$ & $2.08^{\mathrm{b}}$ & $1.88^{\mathrm{c}}$ \\
\hline $\mathrm{p}-$ value & 0.0026 & 0.0001 & 0.0001 \\
\hline SEM & 0.01 & 0.006 & 0.004 \\
\hline
\end{tabular}

\section{DISCUSSION}

Ipek et al. (2004), investigating the effect of in-ovo injection of different levels glucose in broiler breeder eggs on hatchability, reported that eggs injected with $0.5 \mathrm{ml}$ of deionized sterile water containing 5, 10 and 15 $\mathrm{mg}$ of glucose did not differ significantly. On the other hand, in the present study, the injection of glucose in the albumen reduced hatchability, Another study also showed that the injection of glucose in the albumen reduced the hatching percentage of newly-hatched chicks compared with the control group (Bhanja et al., 2008). Also, Pedroso et al. (2006) observed that, when chick embryos received an in-ovo injection of glucose at 16 days of incubation, hatchability decreased.

The observed reduced hatchability possibly results from the injection in the albumen, that may have caused an allergic reaction under the air sac that stopped the respiration of the developing embryo, causing its death. Previous studies showed that on in-ovo administration of hormones such as corticosteroids on embryonic day 7 resulted in 35\% decline of hatchability (Heiblum et al. 2001). All reviewed studies relative to in-ovo manipulation, including the present study, especially in early embryonic life, were not successful in terms of hatchability (Kocamis et al. 1998; Kocamis et al. 1999; Lamosova el al. 2003; Heiblum et al. 2001).

Accelerated embryo development and improved nutritional status afforded by in-ovo feeding improved hatching weight and growth rate (Al-Murrani, 1982; Ohta et al., 1999; Bhanja et al., 2004). Chen et al. (2009) stated that the in-ovo injection of carbohydrates improved duck weight gain in the early days of post-hatch. In the present study, the weight of newly-hatched chickens was significantly higher when glucose was injected in-ovo compared with that of the control and sham groups. Previous studies demonstrated that the weight of newlyhatched chickens is an important predictor of market weight in chickens. Although this correlation between hatching weight and market weight may differ among strains, the effect of hatch weight on market weight apparently increases as broiler breeding companies continue to select for ever-increasing growth rates (Wilson, 1991; Vieira \& Moran, 1999a, b; Havenstein et al., 2003). Wilson (1991) indicated that each $1 \mathrm{~g}$ of increase in body weight at hatch resulted in 8 to $13 \mathrm{~g}$ increase in body weight at market age. In this study, we showed that an one $g$ of increase in body weight at hatch due to in-ovo injection of glucose resulted in 60 to $63 \mathrm{~g}$ of increase in body weight on day 42 . Amitav et al. (2007) demonstrated that the in-ovo injection of glucose in the eggs of small white turkeys had significantly higher body weight throughout the experimental period and, at 6 weeks of age, there was a difference of 76-78 $\mathrm{g}$ in body weight between the glucose-injected groups and the control group. In the present study, results were consistent with the report of Amitav et al. (2007) on broiler body weight. This additional energy source probably supported the late development of the embryo, resulting in a significant increase in the weight of newly-hatched chickens and their subsequent performance. Leitao et al. (2008) concluded that, the in-ovo injection of glucose had no 
effect on the chicken performance. However, in the present experiment, chicks hatched from eggs injected with glucose presented better weight gain and feed conversion ratio compared with those hatched from eggs of the control and sham groups throughout the experimental rearing period. Bhanja et al. (2008) also showed that the feed conversion ratio during early post-hatch period was better in the glucose-injected group than the control group. Nevertheless, age, strain, egg size or flock broiler breeder conditions may influence the performance of broilers. Therefore, it can be suggested that the effect of glucose should be examined considering those factors.

\section{ACKNOWLEDGMENTS}

We are thankful to Jalil Dolghari-Sharaf for his help in the conduction of the in-ovo injection procedure and laboratory analysis. The present manuscript was summarized from the M.Sc. thesis in Animal Science (Animal nutrition) of the author.

\section{REFERENCES}

Al-Murrani WK. Effect of injecting amino acids into the egg on embryonic and subsequent growth in the domestic fowl. British Poultry Science 1982; 23: 171-174.

Amitav B, Majumdar S, Bhanja SK, Mandal AB, Dash BB, Agarwal SK. Effect of in ovo injection of glucose on growth, immunocompetence and development of digestive organs in turkey poults. Proceedings of the $16^{\text {th }}$ European Symposium on Poultry Nutrition; 2007; Strasbourg. France. p.147-150

Bhanja SK, Mandal AB, Agarwal SK, Majumdar S. Effect of In ovo glucose injection on the post hatch-growth, digestive organ development and blood biochemical profiles in broiler chickens. Indian Journal of Animal Science 2008; 78:869-872.

Bhanja SK, Mandal AB, Goswami TK. Effect of in ovo injection of amino acids on growth, immune response, development of digestive organs and carcass yield of broiler. Indian Journal of Poultry Science 2004;39: 212-218.

Christensen VL, Grimes JL, Donaldson WE, Lerner S. Correlation of body weight with hatchling blood glucose concentration and its relationship to embryonic survival. Poultry Science 2000;79:1817-22.

Duncan JW. Multiples range and multiple F tests. Biometrics 1955; 11: 1-42.

Hamer MJ, Dickson AJ. Influence of developmental stage on glycogenolysis and glycolysis in hepatocytes isolated from chick embryos and neonates. Biochemical Society transactions 1989;17:1107-1108.

Havenstein GB, Ferket PR, Qureshi MA. Carcass composition and yield of 1957 versus 2001 broilers when fed representative 1957 and 2001 broiler diets. Poultry Science 2003;82:1509-1518.

Heiblum R, Arnon E, Chazan G, Robinzon B, Gvaryahu G, Snapir N. Glucocorticoid Administration during Incubation: Embryo Mortality and Posthatch Growth in Chickens. Poultry Science 2001;80:1357-1363.

Ingram DR, Floyd SA, Barr JW, Pittman ST. Influence of in ovo injection of glucose on subsequent body weight. Proceedings of the Poultry Science Association 86 $6^{\text {th }}$ Annual Meeting Abstracts; 1997; Athens, Georgia. USA. 1151

Ipek A, Sahan U. Yilmaz B. The effect of in ovo ascorbic acid and glucose injection in broiler breeder eggs on hatchability and chick weight. Archiv für Geflügelkunde 2004; 63:132-135.

Kocamis H, Kirkpatrick-Keller DC, Klandorf H, Killefer J. In Ovo Administration of Recombinant Human Insulin-Like Growth Factor-I Alters Postnatal growth and development of the broiler chicken. Poultry Science 1998 ; 77: 1913-1919.

Kocamis H, Yeni YN, Kirkpatrick-Keller DC, Killefer J. Postnatal growth of broilers in response to in ovo administration of chicken growth hormone. Poultry Science 1999;78:1219-1226.

Lamosova D, Macajova M, Zeman M, Moze D, Ova JE. Effect of in ovo leptin administration on the development of Japanese quail. Physiological Research 2003;52:201-209.

Leitao RA, Leandro NSM, Café MB, Stringhini JH, Pedroso AA, Chaves LS. Inoculation of glucose in ovo of broiler breeders/eggs: incubation parameters and initial performance. Ciência Animal Brasileira 2008;9:847-855.

NRC - National Research Council, Nutrient requirements of poultry. $9^{\text {th }}$ ed Washington (DC): National Academy Press; 1994.

Ohta $Y$, Kidd MT, Ishibashi T. Embryo growth and amino acid concentration profiles of broiler breeder eggs, embryos, and chicks after in ovo administration of amino acids. Poultry Science 2001; 80:1430-1436.

Ohta Y, Tsushima N, Koide K, Kidd MT, Ishibashi T. Effect of amino acid injection in broiler breeder eggs on embryonic growth and hatchability of chicks. Poultry Science 1999;78:1493-1498.

Pedroso AA, Chaves LS, Lopes KLA, Leandro NSM, Café MB, Stringhini JH. Nutrient inoculation in eggs from heavy breeders. Revista Brasileira de Zootecnia 2006:5:2018-2026.

SAS Institute. SAS user's guide. $8^{\text {th }}$ ed. Cary; 2001.

Stryer L. Biochemistry. $4^{\text {th }}$ ed. New York: Freeman WH. and Company; 1995. p.483-509.

Vieira SL, Moran ET. Effects of delayed placementand used litter on broiler yields. Journal of Applied Poultry Research 1999a;8:75-81.

Vieira SL, Moran ET. Effect of egg origin andchick posth-hatch nutrition on broiler live performanceandmeat yields. World's Poultry Science Journal 1999b;56:125-142.

Wilson $\mathrm{JH}$. Bone strength of caged layers as affected by dietary calcium and phosphorus concentrations, reconditioning, and ash content. British Poultry Science 1991;32:501-508. 